\title{
Specific periodization for the volleyball: a training organization
}

\begin{abstract}
The specific periodization for the volleyball was elaborate with the influence of the traditional periodization of Matveev, with some contents of the structural scheme of high intensity loads of Tschiene, of the block periodization of Verkhoshanski, of the non-linear periodization elaborate by the Americans, of the periodization of selective loads of Gomes and of the tactical periodization of Vitor Frade. The objective of the review article was to explain how the volleyball coach organizes the ball training with the specific periodization for the volleyball. The volleyball player works a skill during the technical training with the objective of improve the biomechanics of the sports technique. During the game situation training the volleyball player practices two or more skill in the sequence defined of the volleyball match. Therefore, training load of the technical training and of the game situation training is in accordance with the skill prescribed during the volleyball training because the effort of each volleyball skill with the result of the heart rate in beats per minute determined the skills with more and less effort. The game training the control of the skills effort is difficult of measure before of the training. The specific periodization for the volleyball has the characteristics of elaborates the volleyball skills of the technical training and of the game situation training according with the objective of the training and with the volleyball skill effort. In conclusion, specific periodization for the volleyball has the objective of improve the athlete performance with a subjective control during the training
\end{abstract}

Keywords: volleyball, training, effort, periodization, sports
Volume 2 Issue 3 - 2018

\author{
Nelson Kautzner Marques Junior ${ }^{1,2}$ \\ 'Department of Science of the Human Motricity, Brazil \\ ${ }^{2}$ Member, Scientific Committee of the Revista Observatorio del \\ Deporte, Chile
}

Correspondence: Nelson Kautzner Marques Junior, Department of Science of the Human Motricity, Brazil, Email kautzner|23456789junior@gmail.com

Received: March 29, 2018 | Published: May 30, 2018

\section{Introduction}

The sports periodization started during the Olympic Games of the Antiquity with the Greek athletes. ${ }^{1}$ Soviet Union had attention about the periodization after the Russian Revolution of $1917^{2,3}$ and this country practiced several studies about periodization with the objective of improve this training content. ${ }^{4}$ However, the periodization for the type of sport needs to be in agreement with the characteristics of the sport. ${ }^{5}$ Then, Marques Junior ${ }^{6}$ elaborated the specific periodization for the volleyball with purpose of organizes the volleyball training. The specific periodization for the volleyball is new because this model was elaborated in 2011 (had 8 years, 2011 to 2018) by the Brazilian Marques Junior ${ }^{6}$ who played indoor volleyball and beach volleyball in Rio de Janeiro, Brazil. This periodization model has the content for improve the volleyball training with an organization of the volleyball skills during the technical training and the game situation training. Others types of training of the specific periodization for the volleyball are the game training and the physical training. The training load and the fatigue were monitored with subjective perception scale during the use this periodization. ${ }^{8}$ The specific periodization for the volleyball was elaborate with the influence of the traditional periodization of Matveev, ${ }^{9}$ with some contents of the structural scheme of high intensity loads of Tschiene, ${ }^{10}$ of the block periodization of Verkhoshanski, ${ }^{11}$ of the non-linear periodization elaborate by the Americans, ${ }^{12}$ of the periodization of selective loads of Gomes ${ }^{13}$ and of the tactical periodization of Vítor Frade. ${ }^{14}$ The author of the specific periodization for the volleyball used some contents these periodization models because the volleyball literature determined high performance with these types of periodization of the volleyball player. ${ }^{15-18}$ The figure 1 illustrates the content used of others models in the specific periodization for the volleyball.

Then, a review about the specific periodization for the volleyball for the volleyball is important because this model has only three studies with language in Portuguese. ${ }^{6-8}$ Therefore, a review in English is important for this periodization has more volleyball coaches using this model. The objective of the review article was to explain how the volleyball coach organizes the ball training with the specific periodization for the volleyball.

\section{Training structure with the specific periodization for the volleyball during the ball training}

The volleyball match has a sequence of skills defined during the game. ${ }^{19}$ The serve starts the match or the volleyball player has the objective of practice a point. ${ }^{20}$ Reception and set has the action of construction and offensive development. ${ }^{21}$ The attack is the skill most decisive skill in the volleyball victory because this skill causes more points. ${ }^{22}$ The block is an important skill because practices a point or avoid the point. ${ }^{23}$ The defense has the objective of avoid the point and starts the counterattack. ${ }^{24}$ The Figure 1 illustrates the defined sequence of the skills during the volleyball match.

The volleyball player works a skill during the technical training with the objective of improve the biomechanics of the sports technique..$^{25}$ But during the game situation training the volleyball player practices two or more skill in the sequence defined of the volleyball match (Figure 2). Then, Arruda and Hespanhol ${ }^{26}$ determined that the greatest efforts in the volleyball are the jump skills and after the defensive 
displacements. Therefore, training load of the technical training and of the game situation training is in accordance with the skill prescribed during the volleyball training. ${ }^{27}$ For example, tactical training and attack had highest subjective perception of effort of $6 \pm 1,6$ (medium effort) of the Foster scale, in second place of the subjective perception of effort was the tactical training with $5,9 \pm 2$ (medium effort), in third place was the block training with 5,8 2 (medium effort) and others. ${ }^{28}$ Tactical training occurs during the game and is with more effort. Attack and block the volleyball player needs of high jump and the athlete practices with high effort. Marques Junior ${ }^{8}$ determined the effort of each volleyball skill with the result of the heart rate in beats per minute (bpm). The Figure 3 illustrates the values.

Then, the game situation training of overhand serve and reception has a less effort than the technical training of attack. Therefore, the skill effort is important for the coach determines the training load subjectively before of the athlete practices the training. ${ }^{7}$ For example, a training structure of a day the Figure 4 illustrates. After the training, the volleyball coach shows for the volleyball player the faces scale of the subjective perception of effort adapted of Foster for determine the intensity ${ }^{29}$ and the faces scale of the subjective perception of the muscle soreness of the physical effort of the volleyball for determine the fatigue. ${ }^{30,31}$ The Figure 5A, Figure 5B illustrates two scales. The use of the faces scale of the subjective perception of effort adapted of Foster is important for the coach calculates the training load, the monotony of loads and strain loads recommended by Foster et al. ${ }^{32}$ Marques Junior ${ }^{8}$ explained in details these calculations, but the reader needs to consult this article. The specific periodization for the volleyball has a limitations, the author practiced little research about this model, ${ }^{33}$ but actually is the only periodization model elaborate for the volleyball. The article is finished with the schematic drawing that represents the specific periodization for the volleyball.

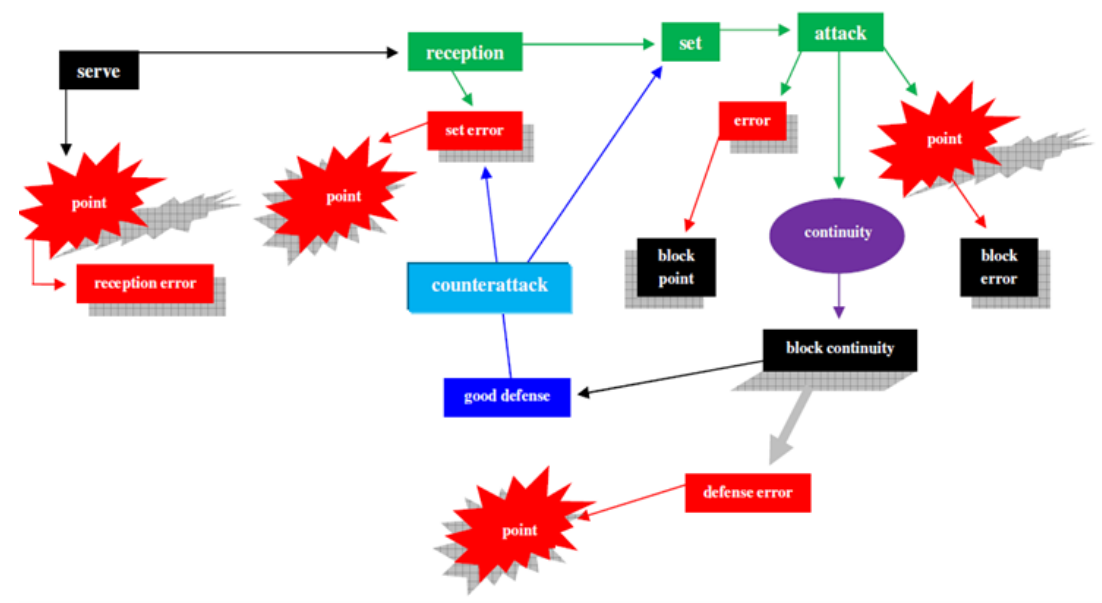

Figure I Volleyball skills during the volleyball match.

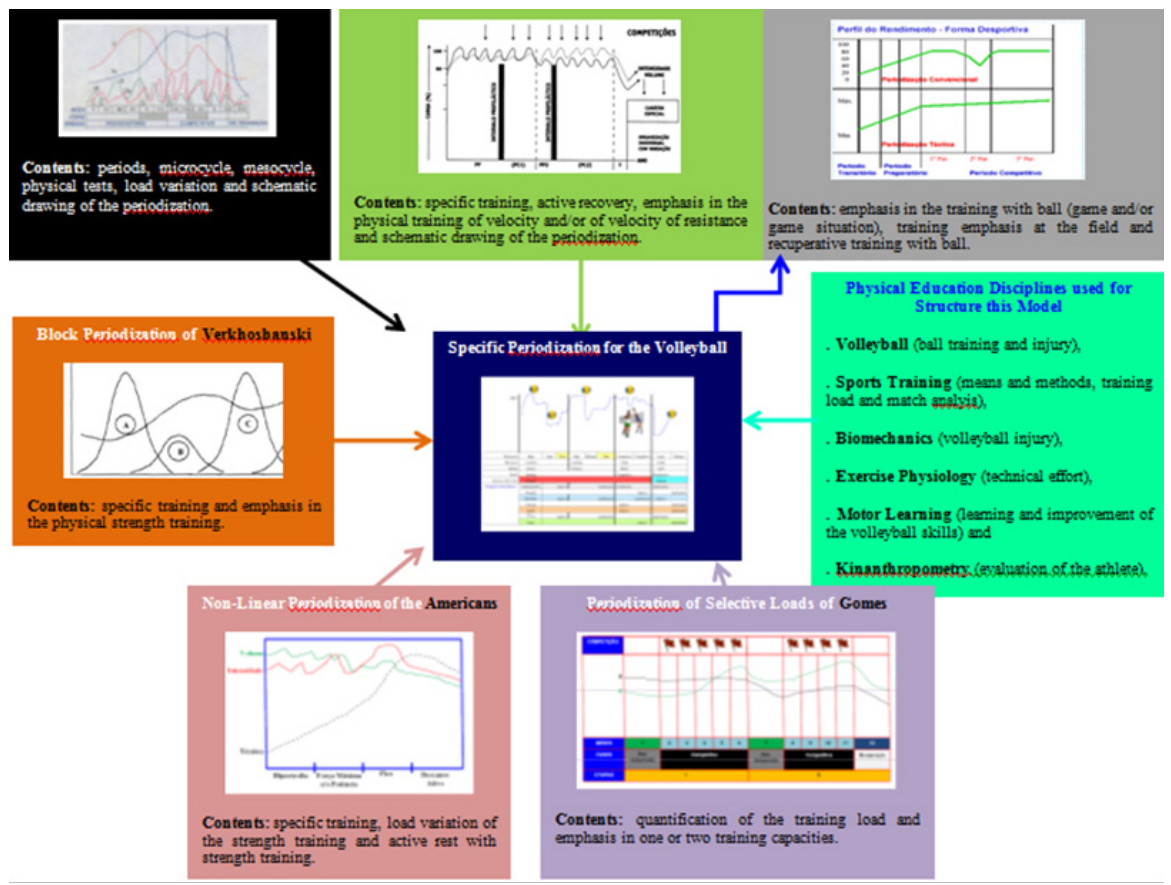

Figure 2 Contents of other models of periodization that Marques Junior7,8 used for the elaboration of the specific periodization for the volleyball. 


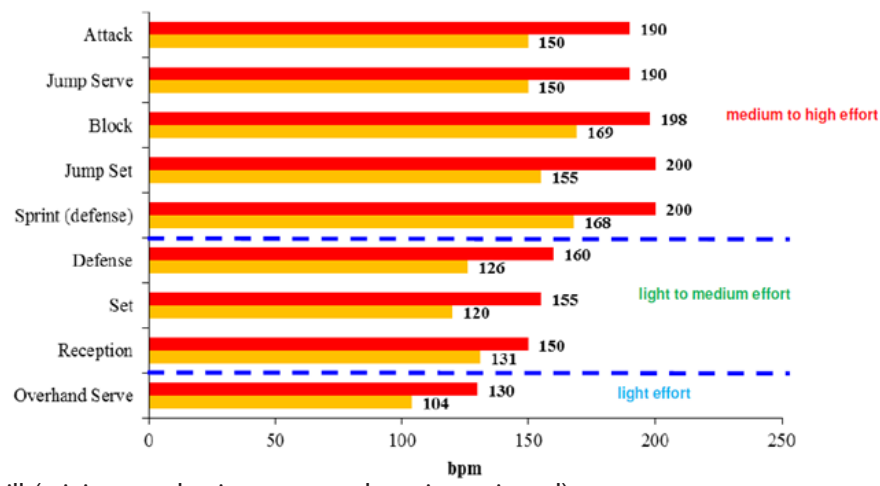

Figure 3 Heart rate of the volleyball skill (minimum value in orange and maximum in red).

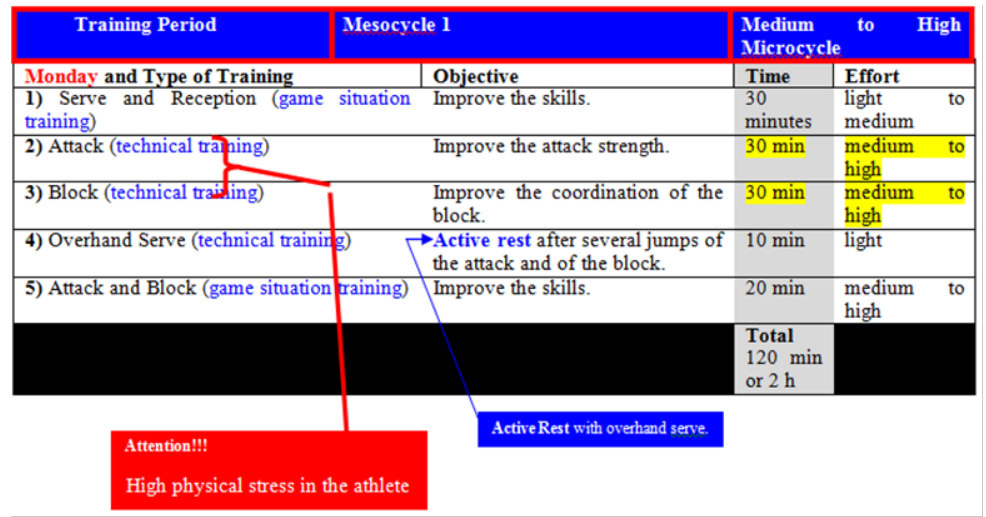

Figure 4 Training structure of the specific periodization for the volleyball.

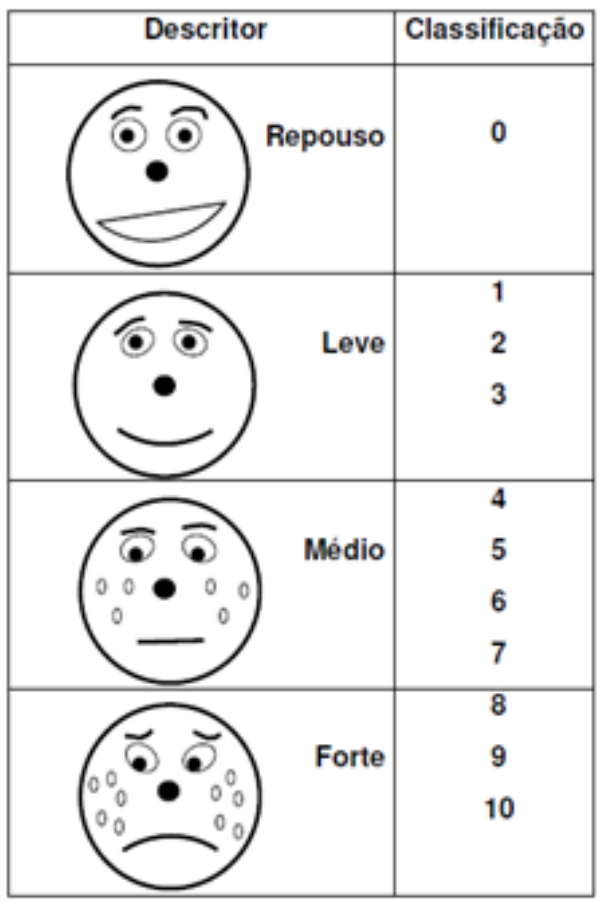

Figure 5A Faces scale of the subjective perception of effort adapted of Foster

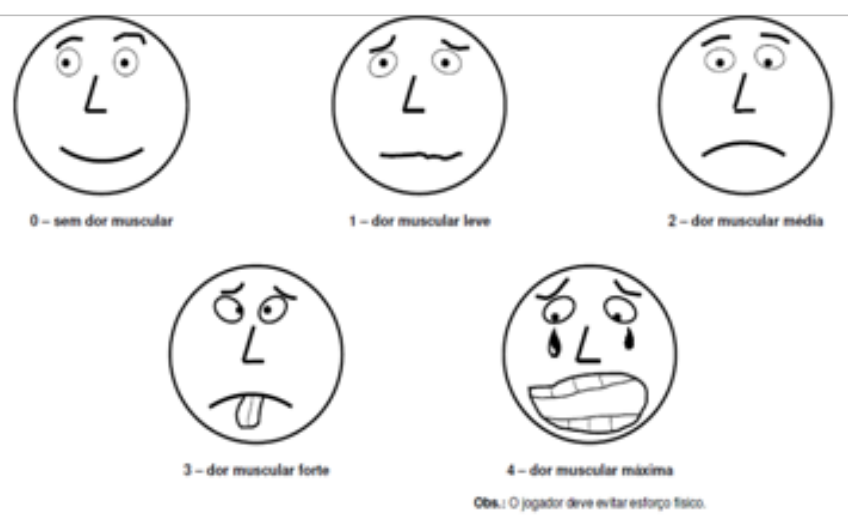

Figure 5B Faces scale of the subjective perception of the muscle soreness of the physical effort of the volleyball.

\section{Conclusion}

The specific periodization for the volleyball has the characteristics of elaborates the volleyball skills of the technical training and of the game situation training according with the objective of the training and with the volleyball skill effort. But the game training the control of the skills effort is difficult of measure before of the training. Therefore, this periodization model has the objective of training structure with a subjective control of the volleyball skill effort. In conclusion, specific periodization for the volleyball has the objective of improve the athlete performance with a subjective control during the training. 


\section{Acknowledgements}

The author thanks the MOJ Sports Medicine invitation for write an article.

\section{Conflict of interests}

Author declares that there is no conflict of interest.

\section{References}

1. Marques JN. Periodização do treino. Educ Fís Rev. 2012;6(2):1-34

2. Marques JN. A Revolução Russa e o desenvolvimento da periodização esportiva na União Soviética. Rev Incl. 2017;4(esp):110-127.

3. Padilla J. Planificación del entrenamiento deportivo: un enfoque metodológico de la estructura clásica. Barinas-Venezuela: Episteme; 2017. p. 13-24

4. Marques JN. Planificación del entrenamiento deportivo de José Padilla: um livro sobre a periodização clássica. Rev Observatorio Dep. 2018;4(1):68-75.

5. Garganta J. Programação e periodização do treino em futebol: das generalidades à especificidade. In: Bento $\mathrm{J}$, Marques A, editors. $A$ ciência do desporto a cultura e o homem. Porto: Universidade do Porto; 1991. p. 259-270.

6. Marques JN. Modelos de periodização para os esportes. Rev Bras Prescr Fisio Exerc. 2011;5(26):143-62.

7. Marques JN. Periodização específica para o voleibol: atualizando o conteúdo. Rev Bras Prescr Fisio Exerc. 2014;8(47):453-84.

8. Marques Junior N. Periodização específica para o voleibol: atualizando o conteúdo da carga de treino. Rev Observatorio Dep. 2017;3(4):32-60.

9. Matveev L. Fundamentos do treino desportivo $2^{a}$ edn. Lisboa: Horizonte; 1991

10. Tschiene P. As novas teorias de planeamento de treino. Rev Atletismo. 1992;122:28-9

11. Verkhoshanski Y. Preparação de força especial. Rio de Janeiro: GPS; 1995.

12. Kraemer W, Häkkinen K. Treinamento de força para o esporte. Porto Alegre: Artmed; 2004

13. Gomes A. Treinamento desportivo: estruturação e periodização $2^{\mathrm{a}}$ ed Porto Alegre: Artmed. 2002

14. Carvalhal C. No treino de futebol de rendimento superior. A recuperação é... muitíssimo mais que "recuperar”. Braga: Liminho, 2001.

15. Grigoletto M, Puerto J, Montaner B, et al. Comportamiento de diferentes manifestaciones de la resistencia en el voleibol a lo largo de una temporada, en un equipo profesional. Rev Andaluza Med Dep. 2008;1(1):3-9.

16. Marques JN. Estudo de um jogador do voleibol na areia: verificação do preparo físico e a identificação do fluxo sanguíneo cerebral, 1999 a 2013. Rev Bras Prescr Fisio Exerc. 2015;9(55):462-74.
17. Oliveira P, Silva J. Dinâmica da alteração de diferentes capacidades biomotoras nas etapas e micro-etapas do macro-ciclo anual de treinamento de atletas de voleibol. Rev Trein Desp. 2001;6(1):18-30.

18. Rigolin SL, Franchini E, Kiss M, et al. Evolução da altura de salto, da potência anaeróbia e da capacidade anaeróbia em jogadores de voleibol de alto nível. Rev Bras Ci Esp. 2004;26(1):99-109.

19. Marques JN, Arruda D. Fundamentos praticados por uma equipe feminina de voleibol sub 15 durante o campeonato paranaense de 2015 . Educ Fís Ci. 2017;19(1):1-17.

20. Costa Y, Sousa M, Silva J, et al. Indicadores de rendimento técnicotático em função do resultado do set no voleibol escolar. Motr. 2017;13(SI):34-40.

21. Marques Junior N. Evidências científicas sobre os fundamentos do voleibol. Rev Bras Prescr Fisio Exerc. 2013;7(37):78-97.

22. Cieminski K. The efficiency of executing technical actions by female volleyball players depending on their positions on the court. Baltic $J$ Health Phys Activ. 2017;9(3):44-52.

23. Conejero M, Claver F, Silva J, et al. Analysis of performance in game actions in volleyball, according to the classification. Rev Port Ci Desp. 2017;17(SIA):196-204

24. Afonso J, Laporta L, Mesquita I. A importância de diferenciar o KII do KIII no voleibol feminino de alto nível. Rev Port Ci Desp. 2017;17(SIA):140-7.

25. Marques JN. Ensino dos jogos esportivos coletivos: uma revisão sobre o voleibol. Refeld. 2009;4(4):186-93.

26. Arruda M, Hespanhol J. Fisiologia do voleibol. São Paulo, Phorte. 2008.

27. Marques JN. Carga de treino do esporte de alto rendimento: revisitando o conteúdo. Rev Europa del Este Unida. 2017;(3):42-74.

28. Horta T, Filho BM, Miranda R, et al. Influência dos saltos verticais na percepção da carga interna de treinamento no voleibol. Rev Bras Med Esp. 2017;23(5):403-6.

29. Marques JN. Confiabilidade da escala de faces da percepção subjetiva do esforço adaptada de Foster: um estudo no voleibol master. Rev 100 Cs. 2017;3(1):29-42.

30. Marques JN, Arruda D, Nievola Neto G. Validade e confiabilidade da escala de faces da percepção subjetiva da dor muscular do esforço físico do voleibol: um estudo durante a competição. Rev Observatorio Dep. 2016;2(1):26-62.

31. Marques JN. Confiabilidade da escala de faces da percepção subjetiva da dor muscular do esforço físico do voleibol: um estudo no voleibol master. Rev Bras Prescr Fisio Exerc. 2017;11(67):405-15.

32. Foster C, Florhaug J, Franklin J, et al. A new approach to monitoring exercise training. J Strength Cond Res. 2001;15(1):109-15.

33. Marques JN, Barbosa O. Lesão no tendão calcâneo de um atleta de voleibol: relato de experiência. Rev Observatorio Dep. 2016;10(57):29-66 